\title{
Breast Cancer Incidence and Early Diagnosis in a Family History Risk and Prevention Clinic: 33-Year Experience in 14,311 Women
}

\section{Gareth R. Evans ( $\nabla$ gareth.evans@cmft.nhs.uk)}

St. Mary's Hospital https://orcid.org/0000-0002-8482-5784

Sacha J Howell

Christie Hospital

Ashu Gandhi

MFT: Manchester University NHS Foundation Trust

Elke $M$ van Veen

University of Manchester School of Biological Science: The University of Manchester Faculty of Biology Medicine and Health

\section{Emma R Woodward}

MFT: Manchester University NHS Foundation Trust

\section{James Harvey}

MFT: Manchester University NHS Foundation Trust

Lester Barr

MFT: Manchester University NHS Foundation Trust

Andrew Wallace

MFT: Manchester University NHS Foundation Trust

Fiona Lalloo

MFT: Manchester University NHS Foundation Trust

Mary Wilson

MFT: Manchester University NHS Foundation Trust

Emma Hurley

MFT: Manchester University NHS Foundation Trust

Yit Lim

MFT: Manchester University NHS Foundation Trust

Anthony J Maxwell

University of Manchester School of Medicine: The University of Manchester Faculty of Biology Medicine and Health

Elaine F. Harkness

University of Manchester School of Medicine: The University of Manchester Faculty of Biology Medicine and Health

Anthony Howell

University of Manchester School of Medicine: The University of Manchester Faculty of Biology Medicine and Health

\section{Research Article}

Keywords: BRCA1, BRCA2, breast cancer, mammography, MRI, screening

Posted Date: February 19th, 2021

DOI: https://doi.org/10.21203/rs.3.rs-236542/v1

License: @) (1) This work is licensed under a Creative Commons Attribution 4.0 International License. Read Full License

Version of Record: A version of this preprint was published at Breast Cancer Research and Treatment on July 26th, 2021. See the published version at https://doi.org/10.1007/s10549-021-06333-1. 


\section{Abstract}

Purpose:Women at increased familial breast cancer risk have been offered screening starting at an earlier age and increased frequency than national Screening Programmes for over 30years. There are limited data on longer-term largescale implementation of this approach on cancer diagnosis.

Methods:Women at our institution at $\geq 17 \%$ lifetime breast cancer risk have been offered enhanced screening with annual mammography starting at age 35 or 5 -years younger than youngest affected relative, with upper age limit 50 for moderate and 60 for high-risk. Breast cancer pathology, stage and receptor status were assessed as well as survival from cancer diagnosis by Kaplan-Meier analysis.

Results:Overall 14,311 women were seen and assessed for breast cancer risk, with 649 breast cancers occurring in 129,119.5 years follow up (post-prevalent annual incidence $=4.55 / 1,000)$. Of 323/394 invasive breast cancers occurring whilst on enhanced screening, most were LN negative (72.9\%), T1 $(\leq 20 \mathrm{~mm}, 73.2 \%)$ and stage-1 (61.4\%). Ten-year breast cancer specific survival was $91.3 \%(95 \% \mathrm{Cl}=87.4-94.0)$ significantly better than the $75.9 \%(95 \% \mathrm{Cl}=74.9$ 77.0) published for England in 2013-2017. As expected, survival was significantly better for women with screen detected cancers( $<<0.001)$. Ten-year survival was particularly good for those with diagnosed $\leq 40$ at $93.8 \%(n=75 ; 95 \% \mathrm{Cl}=84.2-97.6)$. Women with lobular breast cancers had worse 10 -year survival at $85.9 \%(95 \% \mathrm{Cl}=66.7-94.5)$. Breast cancer specific survival was good for $119 \mathrm{BRCA1/2}$ carriers with 20-year survival in $B R C A 1: 91.2 \%(95 \% \mathrm{Cl}=77.8-96.6)$ and 83.8\% (62.6-93.5) for BRCA2

Conclusions:Targeted breast screening in women aged 30-60 years at increased familial risk is associated with good long-term survival that is substantially better than expected from population data.

\section{Introduction}

Breast cancer (BC) is the most common cancer in females with approximately 54,500 women diagnosed annually in the UK (2016) and remains the leading cause of premature death in women aged 30-60 years.[1] Epidemiological studies suggest that $\sim 4-5 \%$ of BC is caused by high-risk genes,[2] but twin studies suggesting $27 \%$ have inherited factors.[3] The cloning of BRCA1 and BRCA2 in 1994-1995[4,5] allowed predictive testing to identify which women had highest risk. Other high-penetrance BC genes (lifetime-risk >40\%) including TP53, PTEN, CDH1, STK11 and PALB2 have also been identified,[6,7] as well as moderate-risk genes (lifetime-risk 20-30\%) ATM and CHEK2.6

Family history risk and prevention clinics (FHRPC) began appearing in 1987.[8] A method of triage was developed such that women with moderate BC risk (lifetime-risk 17-29\%) were managed in local FHPRCs and high-risk women (lifetime risk $\geq 30 \%$ ) were referred to genetics clinics.[9] This process was endorsed in the UK by the National Institute for Health and Care Excellence (NICE) in 2004 whose guidance covered recommendations on BC risk assessment, genetic testing, surveillance and risk reducing surgery.[10] Most FHRPCs offered pragmatic annual breast screening from five years before the earliest BC diagnosis in the family or from 35 years whichever was earlier.[9] NICE originally advised annual mammographic screening only from 40-49 years for moderate and highrisk individuals, but updated the guidance in 200610 to include MRI screening for women at the highest risk after the publication of a number of MRI screening trials.[11-14] In 2013, following publication of the FH01 study, annual mammographic screening in women aged 40-49 at moderate and high-risk[15] was fully endorsed by NICE and annual mammography for high-risk women from 50-59 years. 10 Since then, screening with annual mammography between ages 35-39 years has also been shown to detect BC at earlier stages with anticipated improvement in survival.[16] The outcomes from a largescale systematic approach utilising family history to enhance early detection rates by mammography screening has not yet been published to our knowledge.

A FHRPC was established in Manchester in 1987[17] and was the forerunner to other similar clinics in Europe. We report here the outcome of risk assessment and surveillance in 14,311 women referred to the Manchester FHPRC clinic between 1987-2020.

\section{Materials And Methods}

Women with a BC family history, but unaffected personally, have been referred to the FHRPC at the Nightingale Centre Withington/Wythenshawe hospital since 1987. Their lifetime and residual risk of BC has been assessed using questionnaire information on family history and standard risk factors using Claus tables and the Tyrer-Cuzick programme.[1,17-19] Women were classified as being high-risk (lifetime-risk $\geq 30 \%$ ), moderate-risk (lifetime-risk-17-29\%) or average/population risk (lifetime-risk-<17\%). Average-risk women were returned to primary care with reassurance and information on breast awareness and advised to start or continue screening from age 50. Moderate-risk and high-risk women were offered 'enhanced' surveillance (annual mammography and clinical breast examination (CBE)) starting at 35years or 5years younger than youngest affected relative (earliest age 30 ). With upper age limit 50 for moderate and 60 for high-risk. For high-risk women 'enhanced' surveillance continued at 12-18 monthly intervals from 50-60 years of age and started as young as age 30 (if $B R C A 1 / 2$ or youngest relative <35). Women from families eligible for genetic testing ( $20 \% B R C A 1 / 2$ likelihood $2004-2013,10 \%$ likelihood $>2013)$ were referred to Genetics. Women with proven $B R C A 1 / 2$ pathogenic variants (PVs) in the family were offered targeted testing for their familial variant. In contrast, unaffected women (without BC) with a significant family history have only been offered a full BRCA1/2 screen since 2013 if an affected family member is unavailable and their a priori likelihood of a $B R C A 1 / 2 \mathrm{PV}$ is $\geq 10 \%$.[11] BRCA1/2 pathogenic variant (PV) carriers have been offered annual MRI screening aged 30-50 years since 2006.10 However, some aged 35-50 years had MRI screening through the MARIBS trial from 1997.[12] Women with lifetime BC risks $\geq 25 \%$, including BRCA1/2 carriers, have had bilateral risk-reducing mastectomy (BRRM) discussions since 1994 .

All FHRPC women seen from 1987 (including discharged) had assessment of vital (living/dead) and cancer status through the regional cancer registry and NHS systems in December-2012. Post 2012, deaths were notified to the clinic and BC incidence was only assessed in those under ongoing surveillance. Women were censored for BC incidence at: BC diagnosis, BRRM, or death, if none, at last mammography (latest March 2020) or 01/12/2012. Data on all BCs occurring in the screening programme including interval cancers occurring within 18-months of last mammogram were collated. This included pathology (invasive-ductal, lobular, ductal carcinoma in situ (CIS)), tumour size, lymph node (LN) status and oestrogen(ER)/progesterone and HER2 receptor status. 
HER2 testing was only available from 2005. ER+HER2- and triple negative BC (TNBC) groups include HER2 untested from <2005 as only $8.6 \%$ (6/70) and 7.3\% $(10 / 137)$ of subsequent tests on invasive ductal cancer for ER- and ER+ respectively were also HER2+. Vital status was established on all BC cases in April2020 and causes of death confirmed from cancer records and death certification.

BCs were defined as detected 'on programme' if they were diagnosed at screening episodes or within 18-months (interval cancers). Most women off programme were discharged to population breast screening on the 3-yearly basis NHS breast screening programme aged 50 if moderate-risk and 60 if highrisk.

In addition to clinical BRCA1/2 (including CHEK2 c.1100delC) testing where indicated by likelihood of a BRCA1/2 PV, many families received testing of affected members through the Familial BC Study (FBCS) and 1300 women (900 without BC) consenting to the FHrisk study had testing of an extended panel of $\mathrm{BC}$ genes through the BRIDGES study.[20]

\section{Annual incidence rates}

Annual incidence rates were calculated excluding cancers at prevalent screen. The BRCA1 and BRCA2PV carrier groups were eligible for follow up from testing date or date of clinic entry which ever was later. PV carriers tested after BC diagnosis were included in the untested group if their family PV was known at diagnosis or to the appropriate risk category at clinic entry if their family PV was identified after diagnosis. Likewise, those testing negative for their family BRCA1/2 PV were eligible from date of negative test and excluded from prospective analysis as a PV carrier if testing was after diagnosis. All other women were grouped with their original risk category including the small group of 31 women with other known moderate/high risk gene PVs at entry. The 16 patients with neurofibromatosis-1 (NF1) were classified as moderate risk.[21]

\section{Statistical methods}

BC incidence was calculated excluding cancers detected on prevalence screen. Survival was assessed by Kaplan-Meier analysis and the log rank test to compare survival curves for categorical variables. Chi-squared tests were used to compare categorical variables. Differences in pathology variables in cancers on the screening programme used the high risk $B R C A 1 / 2$ negative group as the reference. $B R C A 1$ and $B R C A 2$ incidence and in those testing negative, was only assessed from date of mutation report. All $\mathrm{p}$ values were based on two-sided tests and were considered statistically significant if $<0.05$. Analyses were performed using Stata version 14.

The study was approved by the Central Manchester Research Ethics Committee (10/H1008/24).

\section{Results}

\section{Study Population}

A total of 14,311 women without BC, born between 1920 and 2003 (median: 1966), had their risk of BC assessed (Figure 1). Age at entry ranged from 16-81 years (median=39.9; IQR=33.9-46.9). Detailed study population characteristics are described (Table-1) according to final known genetic status. Seven-hundredand-thirty-six women (5.1\%) have been identified as BRCA PV carriers (BRCA1=364, BRCA2=372)-Table 1. Two-hundred-and-seventy-two (37.0\%) of these were referred into the FHRPC as known PV carriers unaffected by BC. The remainder were identified after clinic entry (Figure-1). As such 298/14,311 (2.1\%) were identified as BRCA PV carriers with no known PV in the family at clinic entry. Overall BRCA testing in the individual woman or affected family member has completed in 4168(29.1\%) clinic attenders. Of 649 women with BC, 539-(83.1\%) had known BRCA status.

\section{Follow-up time}

There have been 129,119.5 women-years follow up with 649 BCs (588 post-prevalent), resulting in annual incidence of $4.55 / 1,000$. This excluded 45 prevalent asymptomatic screen detected cancers $(0.31 \%)$ and a further sixteen women who developed symptomatic BC between referral and clinic attendance. Therefore, there were 61 total prevalent cancers $(0.43 \%-61 / 14311)$. Within the enhanced screening programme there were 63972.4 years follow up, 349 (2.4\%) women developed BC following prevalence screen (incidence=5.46/1000). Four-hundred-and-fifty-five women (455/14311-3.2\%) have undergone presymptomatic BRRM with seven occult BCs (1.5\%) diagnosed at surgery. The remaining 239 cancers occurred after clinic discharge making a total of 255 (including 16 pre-prevalent scan) off programme. Breast cancer incidence by risk group is shown in table 2 . Incidence post prevalence in $B R C A 1$ was $1.73 \%$ and in BRCA2 1.55\% annually from date of mutation report. The low rate in untested women reflects those at $25 \%$ risk and very young women prior to testing. Carriers of known PVs in other genes were included in the lifetime risk category known at entry due to low numbers.

\section{Cancers}

The age and known PV carrier status of the women with BCs are shown in table-3. Cancer pathology on the FHRPC enhanced screening programme is shown in table-4. BRCA7-related BCs were more likely grade 3 and oestrogen receptor negative (ER-) than cases in the high-risk BRCA negative cohort as expected ( $p<0.0001$ for both). Tumours from women who tested BRCA PV negative in the high-risk cohort were more likely to be grade 1 than both $B R C A 1$ ( $p<0.001)$ and BRCA2 ( $\mathrm{p}=0.04$ ) tumours. Only $36 / 394(9 \%)$ women with cancers in the enhanced screening programme had no genetic testing compared with $84 / 255$ (32.9\%) of those off programme. Of the cancers in the enhanced screening programme $70(17.9 \%)$ were carcinoma in situ (CIS) with a higher proportion seen on prevalent screen (33.3\%- supplementary-table-1). The majority of invasive cancers were LN negative (72.9\%), small ( $\leq 20 \mathrm{~mm}-73.2 \%)$ and stage-1 $(61.4 \%)$. BRCA1/BRCA2 PV associated cancers were smaller overall with $75.0 \%$ and $85.4 \%$ being $\leq 20 \mathrm{~mm}$ respectively, potentially reflecting MRI screening in these groups. Overall deaths were lower in women screened on the enhanced-programme (13.8\%) compared with off-programme (20.8\%)-(Table-3), although offprogramme women were older. Of the deaths with BRCA1/2 PVs, 7/16 were unrelated to $\mathrm{BC}$; $B R C A 1-4 / 8$ (ovarian $(\mathrm{n}=2)$, carcinosarcoma 
uterus $(\mathrm{n}=1)$,pancreatic(n=1)) BRCA2-3/8 (ovarian,lung cancer,old-age). Only one each BRCA1 and BRCA2 deaths in carriers were $\mathrm{BC}$ related in women on $\mathrm{MRI}$ screening (2/38). In total $34 / 54(63 \%)$ of deaths in women with cancers detected in the enhanced screening programme were $B C$ related.

BC deaths, as expected, were more frequent in women with symptomatic interval cancers (supplementary-table-1,Figure 2a). Incident screen detected 10-year survival was $91.9 \%-(95 \% \mathrm{Cl}=86.7-95.1)$ vs interval $80.2 \%$ (95\% Cl=68.6-87.9) ( $\mathrm{p}<0.001)$; prevalence screen survival $94.5 \%-(95 \% \mathrm{Cl}=79.8-98.6)$ vs incidence screen $(p=0.052)$. The pathologies with the highest proportion of $\mathrm{BC}$ deaths were lobular $(23.3 \%, 10$-year survival $=85.9 \%(95 \% \mathrm{Cl}=66.7-94.5))$ triple negative (14.3\%;10-year-survival=83.5\% (95\% Cl=72.7-90.3)) and high-grade ER+HER2- cancers (13.0\%;10-year-survival=88.5\%(95\%Cl=74.3-95.1)) although numbers in each group were relatively small limiting statistical comparison. As expected, the lowest proportion of BC specific deaths was noted in those with grade-1 tumours (2.4\%; 10-year-survival=95.5\%(95\% Cl=70.7-99.3)) and $\mathrm{CIS}(2.8 \% ; 10$-year-survival $=98.2 \%(95 \% \mathrm{Cl}=87.6-99.7))$, although $\mathrm{BC}$ specific survival was also excellent in grade-2 ER+HER2- BC (10-year-survival=95.1\% $(95 \% \mathrm{Cl}=85.3-98.4)$. Nearly all triple negative BC deaths occurred in the first 5-years-(Figure $2 \mathrm{~b})$.

Although overall survival was worse in those diagnosed $>50$ years $(10$-year $=83.5 \%-\leq 40$ years- 10 -year $=93.5 \%, p=0.04 ; 41-50$ years- 10 -year $=88.8 \%, p=0.025$ Supplementary figure-1), BC specific survival was virtually identical for all age groups, with 10-year $\leq 40$ years survival $93.8 \%(95 \% \mathrm{Cl}=84.2-97.6$ supplementary-table-1; Figure-2c). For the $\leq 40$ years group with invasive $B C(n=58), 5,10$ and 20-year overall survival was $92.2 \%$ (80.5-97.0), 92.2\% (80.5-97.0) and $79.9 \%$ (59.9-90.6). Survival was not significantly different between BRCA1, BRCA2 and non-BRCA carriers on enhanced screening (Figure-2d) with 20-year BC specific survival particularly good in 60 BRCA1 carriers at 91.5\%-(78.5-96.8) compared to 59 BRCA2 at 85.1\%-(64.1-94.3) and 275 non-BRCA 84.7\%(76.5-90.3). The BRCA2 survival curve crossed over BRCA1 after 10 years. Only 51 BRCA carriers were aware of their status at BC diagnosis. Kaplan-Meier curves comparing BRCA PV carriers who knew their status at diagnosis versus those who did not and BRCA carriers who had MRI versus those who only had mammography are shown in Supplementary Figures 2\&3. Survival in the known carriers and MRI screened $(90.6 \%, 95 \% \mathrm{Cl}=80.3-95.7 \%)$ and $90.1 \%$ $(95 \% \mathrm{Cl}=62.6-97.7 \%)$ 10-year survival respectively), but this was not significantly better than the controls who did not know their status $(94.8 \%$; $95 \% \mathrm{Cl}=68.0-$ 93.2\%) and those not undergoing MRI (87.0\%: $95 \% \mathrm{Cl}=80.6-94.8 \%)$. We also carried out a time dependency analysis and this did not show any advantage to knowing the BRCA status (Supplementary-Figure-4)

Five and 10-year BC specific survival in those with BC detected on programme vs off programme screening was:5-year $94.1 \%$-(95\% $\mathrm{Cl}=91.0-96.1)$ vs $94.3 \%$ (95\% $\mathrm{Cl}=90.5-96.6)$ and 10-year $91.0 \%-(95 \% \mathrm{Cl}=87.2-93.7)$ vs $90.4 \%-(95 \% \mathrm{Cl}=85.7-93.4)$ respectively.

\section{Discussion}

The current study is, to our knowledge, the largest study on systematic local approaches to BC risk assessment and surveillance. In total 649 (4.5\%) of 14311 women developed BC with the majority (394[62\%]) detected on enhanced screening. The majority of BCs were detected at stages 0/1-(270/394-68.5\%) with only 94/394-(23.5\%) interval cancer, seven of which were asymptomatic at BRRM. There were expected BC associations with BRCA1 grade-3 ER-HER2significantly more frequent than high-risk BRCA-negative group ( $\mathrm{p}<0.0001)$. Pure CIS was less frequent in $B R C A 1$ and more frequent in $B R C A 2.22$ There appears to be a stronger signal for low grade BC (28\%) in those testing negative for PVs in high-risk genes suggesting a potential feature of yet to be discovered moderate/high-risk genes.

We have reported a mean annual rate of incident prospective BCs in $B R C A 1 / 2 \mathrm{PV}$ carriers of $1.6 \%(1.55 \% B R C A 2,1.73 \% B R C A 1),[23]$ consistent with currently published $69-72 \%$ risks by age 80 years[24,25] when extrapolated over a 50 -year risk period. This study also provides support for the current NICE recommended annual MRI screening surveillance strategy [11] as there was only one death in a BRCA2 carrier among MRI screened women. This continues to provide efficacy evidence for MRI as an alternative to BRRM.[26] Indeed, nearly half the deaths (44\%) in BRCA1/2 PV carriers with BCs were due to other cancers-(6/16) or old age (1/16).

$\mathrm{BC}$ specific survival was excellent with 10-year survival rates of $91.3 \%-(95 \% \mathrm{Cl}=87.4-94.0)$ noticeably higher than current 10 -year $\mathrm{BC}$ survival in England of all women presenting with primary $\mathrm{BC}$ of $75.9 \%(95 \% \mathrm{Cl}=74.9-77.0 ; 2013-2017$ data).[27] Of particular note is that the 10-year invasive $\mathrm{BC}$ survival $\leq 40 y e a r s$ of $92.2 \%-(95 \% \mathrm{Cl}=80.5-97.0)$ had lower $95 \% \mathrm{Cl}$ above -the UK population based POSH (Prospective-study-of-Outcomes-in-Sporadic-versus-Hereditary-BC) trial. This trial consisted of women presenting with primary BC $\leq 40$ years between 2000-2008.[28] The study found 10-year survival of 73.4\%-(67.4-78.5) for BRCA1/2 vs $70 \cdot 1 \%-(67 \cdot 7-72 \cdot 3)$ for non BRCA BC compared to lower $95 \% \mathrm{Cl}$ of $86.9 \%$ in our population. Indeed, the Kaplan-Meier curves continued to drop towards $50 \%$ by 15 years in POSH28 far below the 20 -year survival from our study of $85.3 \%(77.1-90.7)$ ), and indeed the lower $95 \% \mathrm{Cl}$. Thus, even allowing 18-months lead-time16 survival of women with invasive cancers $\leq 40$ who undergo annual screening is likely significantly better than unscreened women as suggested by the $\mathrm{FH} 02$ study[16].

As expected, women with interval BCs had higher mortality. Most presented within 12-months with known poorer survival.[29] Interestingly stage 2 or more Breast cancer was not different between incident and prevalent cases (27.6\% versus $26.7 \%$ ) among screened population and this is reflected by similar survival rates. This is partly explained by the higher rates of DCIS (33\% versus $20.5 \%$ ). Although women presenting with triple negative cancers had relatively low 5-year survival, at 10-15 years this was no worse than for those with high-grade ER+HER2- BC. Interestingly, invasive lobular BC, known to have higher interval cancer rates29 presumably poorer mammographic sensitivity, was associated with the worst survival. Individuals with a higher risk of lobular cancer including those with $\mathrm{CDH} 1$ pathogenic variants, LCIS or lobular $\mathrm{BC}$ family history should be considered for MRI breast screening.

There are some limitations to the present study. Genetic testing was only carried out in a minority of the screened population although it was performed on the great majority of enhanced programme BCs (91\%) and assessment of incidence rates based on gene testing was not the primary study aim. Most women with BCs had panel testing, allowing extrapolation of likely frequencies of other common familial genes (ATM,CHEK2,PALB2). We do not have follow up for all women after December-2012, but were able to check vital status and cause of death for all women with BC. 
In conclusion, the present study has demonstrated good survival from family history based enhanced-screening approach over a 33-year period. Overall and $\mathrm{BC}$ specific survival is very good and substantially better than would be expected from population statistics and especially $\leq 40$ years who would not otherwise qualify for screening. MRI screening is of benefit to BRCA1/2 carriers and could also be utilised in those at high risk of lobular cancer who are otherwise less well served by mammography.

\section{Declarations}

\section{Acknowledgements and Funding}

DGE, EFH, SJH and AH are supported by the National Institute for Health Research (NIHR) BRC Manchester (Grant Reference Number 1215-200074). This work was also supported by Prevent BC. The authors have no relevant disclosures

\section{Conflicts of interest/Competing interests}

DGE has received consultancy fees from Astrazeneca and Springworks

There are no other conflicts

\section{Availability of data and material (data transparency)}

Raw data available on request

\section{References}

1. https:// accessed April 19th 2020

2. Claus EB, Risch N, Thompson WD Autosomal dominant inheritance of early-onset breast cancer. Implications for risk prediction. Cancer (1994) $1 ; 73(3): 643-51$

3. Lichtenstein P, Holm NV, Verkasalo PK et al (2000) Environmental and heritable factors in the causation of cancer: analyses of cohorts of twins from Sweden, Denmark, and Finland. Engl J Med 343:78-84

4. Miki Y, Swensen J, Shattuck-Eidens D et al (1994) A strong candidate for the breast and ovarian cancer susceptibility gene BRCA1. Science 7(5182):6671266(

5. Wooster R, Bignell G, Lancaster J et al (1995) Identification of the breast cancer susceptibility gene BRCA2. Nature 378(6559):789-792

6. Easton DF, Pharoah PD, Antoniou AC et al (2015) Gene-Panel Sequencing and the Prediction of Breast-Cancer Risk. N Engl J Med 372(23):2243-2257

7. Yang X, Leslie G, Doroszuk A et al. Cancer Risks Associated With Germline PALB2 Pathogenic Variants: An International Study of 524 Families. J Clin Oncol. 2019 Dec 16:JC01901907

8. Evans DGR, Cuzick J, Howell A (1996) Cancer Genetics Clinics. Eur J Cancer 32:391-392

9. Eccles DM, Evans DGR, Mackay J (2000) Guidelines for a genetic risk based approach to advising women with a family history of breast cancer. J Med Genet 37:203-209

10. Mclntosh A, Shaw C, Evans G et al (2004 updated 2006 and 2013) Clinical Guidelines and Evidence Review for The Classification and Care of Women at Risk of Familial Breast Cancer, London: National Collaborating Centre for Primary Care/University of Sheffield. NICE guideline CG164. https://www.nice.org.uk/Guidance/CG164

11. Leach MO, Boggis CR, Dixon AK et al (2005 May) Screening with magnetic resonance imaging and mammography of a UK population at high familial risk of breast cancer: a prospective multicentre cohort study (MARIBS). Lancet 365(9473):21-27 1769-78

12. Kuhl CK, Schrading S, Leutner CC et al (2005 Nov) Mammography, breast ultrasound, and magnetic resonance imaging for surveillance of women at high familial risk for breast cancer. J Clin Oncol 20(33):8469-8476 23(

13. Kriege M, Brekelmans CT, Boetes C et al Magnetic Resonance Imaging Screening Study Group (2004) Efficacy of MRI and mammography for breastcancer screening in women with a familial or genetic predisposition. N Engl J Med 351(5):427-437

14. Warner E, Plewes DB, Hill KA, Causer PA, Zubovits JT, Jong RA, Cutrara MR, DeBoer G, Yaffe MJ, Messner SJ, Meschino WS, Piron CA, Narod SA (2004) Surveillance of BRCA1 and BRCA2 mutation carriers with magnetic resonance imaging, ultrasound, mammography, and clinical breast examination. JAMA 292(11):1317-1325

15. FH01 collaborative teams (2010 Dec) Mammographic surveillance in women younger than 50 years who have a family history of breast cancer: tumour characteristics and projected effect on mortality in the prospective, single-arm, FH01 study. Lancet Oncol 11(12):1127-1134

16. Evans DG, Thomas S, Caunt J et al. Final Results of the Prospective FH02 Mammographic Surveillance Study of Women Aged 35-39 at Increased Familial Risk of Breast Cancer. EClinicalMedicine. 2019 Jan;7:39-46

17. Evans DG, Astley S, Stavrinos P et al (2016 Aug) Improvement in risk prediction, early detection and prevention of breast cancer in the NHS Breast Screening Programme and family history clinics: a dual cohort study. NIHR Journals Library, Southampton (UK)

18. Evans DG, Ingham S, Dawe S et al (2014 Jun) Breast cancer risk assessment in 8,824 women attending a family history evaluation and screening programme. Fam Cancer 13(2):189-196

19. Amir E, Evans DG, Shenton A et al (2003) Evaluation of Breast Cancer Risk Assessment Packages in the Family History Evaluation and Screening Programme. J Med Genet 40(11):807-814 
20. Dorling L, Carvalho S, Allen J et al. Breast cancer risk genes: association analysis of rare coding variants in 34 genes in 60,466 cases and 53,461 controls. N Engl J Med 2020 in press

21. Howell SJ, Hockenhull K, Salih Z, Evans DG. Increased risk of breast cancer in neurofibromatosis type 1: current insights. Breast Cancer (Dove Med Press). 2017 Aug 21;9:531 - 53

22. Lakhani SR, Van De Vijver MJ, Jacquemier J et al (2002) The pathology of familial breast cancer: predictive value of immunohistochemical markers estrogen receptor, progesterone receptor, HER-2, and p53 in patients with mutations in BRCA1 and BRCA2. J Clin Oncol. May 1;20(9):2310-8

23. Kuchenbaecker KB, Hopper JL, Barnes DR et al. Risks of Breast, Ovarian, and Contralateral Breast Cancer for BRCA1 and BRCA2 Mutation Carriers. JAMA. 2017 Jun 20;317(23):2402-2416. doi: 10.1001/jama.2017.7112

24. Evans DG, Harkness E, Lalloo F, Howell A (2014) Long-term prospective clinical follow-up after BRCA1/2 presymptomatic testing: BRCA2 risks higher than in adjusted retrospective studies. J Med Genet 51(9):573-580

25. Mavaddat N, Peock S, Frost D et al (2013) Cancer Risks for BRCA1 and BRCA2 Mutation Carriers: Results From Prospective Analysis of EMBRACE. J Natl Cancer Inst 105(11):812-822

26. Evans DG, Kesavan N, Lim Y, Gadde S et al (2014 Jun) MRI breast screening in high-risk women: cancer detection and survival analysis. Breast Cancer Res Treat 145(3):663-672

27. https://Zero visited 20th July 2020

28. Copson ER, Maishman TC, Tapper WJ et al (2018 Feb) Germline BRCA mutation and outcome in young-onset breast cancer (POSH): a prospective cohort study. Lancet Oncol 19(2):169-180

29. Irvin VL, Zhang Z, Simon MS et al. Comparison of Mortality Among Participants of Women's Health Initiative Trials With Screening-Detected Breast Cancers vs Interval Breast Cancers. JAMA Netw Open. 2020 Jun 1;3(6):e207227

\section{Tables}

Table 1: Risk and gene PV status of all 14311 women assessed at the Manchester FHRPC 


\begin{tabular}{|c|c|c|c|c|c|c|c|c|c|}
\hline gene/risk & number & $\begin{array}{l}\text { breast } \\
\text { cancer }\end{array}$ & $\% B C$ & RRM & \%RRM & deceased & $\begin{array}{l}\text { median age at } \\
\text { entry }\end{array}$ & IQR & $\begin{array}{l}\text { Proportion of } \\
\text { clinic }\end{array}$ \\
\hline$B R C A 1$ & 366 & 77 & $21.04 \%$ & 121 & $33.24 \%$ & 20 & 35.7 & $\begin{array}{l}31.0- \\
42.5\end{array}$ & $2.54 \%$ \\
\hline BRCA2 & 374 & 78 & $20.86 \%$ & 101 & $27.15 \%$ & 19 & 36.9 & $\begin{array}{l}31.9- \\
45.0\end{array}$ & $2.60 \%$ \\
\hline ATM & 18 & 9 & $50.0 \%$ & 0 & $0.00 \%$ & 0 & 41.7 & $\begin{array}{l}37.9- \\
45.0\end{array}$ & $0.11 \%$ \\
\hline $\mathrm{CDH} 1$ & 7 & 2 & $28.57 \%$ & 4 & $57.14 \%$ & 0 & 35.1 & $\begin{array}{l}33.9- \\
46.8\end{array}$ & $0.05 \%$ \\
\hline STK11 & 2 & 0 & $0.00 \%$ & 0 & $0.00 \%$ & 0 & 38.4 & & $0.01 \%$ \\
\hline PTEN & 5 & 2 & $40.00 \%$ & 1 & $20.00 \%$ & 1 & 35.8 & $\begin{array}{l}35.3- \\
36.5\end{array}$ & $0.03 \%$ \\
\hline PALB2 & 13 & 6 & $46.15 \%$ & 0 & $0.00 \%$ & 0 & 38.0 & $\begin{array}{l}34.3- \\
42.0\end{array}$ & $0.09 \%$ \\
\hline CHEK2 & 18 & 7 & $38.89 \%$ & 2 & $11.11 \%$ & 0 & 39.5 & $\begin{array}{l}30.7- \\
44.9\end{array}$ & $0.13 \%$ \\
\hline$N F 1$ & 16 & 0 & $0.00 \%$ & 0 & $0.00 \%$ & 0 & 41.8 & $\begin{array}{l}40.9- \\
44.2\end{array}$ & $0.11 \%$ \\
\hline TP53 & 7 & 3 & $42.86 \%$ & 0 & $0.00 \%$ & 1 & 32.1 & $\begin{array}{l}27.5- \\
34.8\end{array}$ & $0.05 \%$ \\
\hline Negative for $B R C A 1$ in family & 267 & 5 & $1.87 \%$ & 7 & $2.62 \%$ & 0 & 37.5 & $\begin{array}{l}32.1- \\
44.4\end{array}$ & $1.87 \%$ \\
\hline Negative for $B R C A 2$ in family & 271 & 10 & $3.69 \%$ & 6 & $2.21 \%$ & 3 & 39.4 & $\begin{array}{l}32.5- \\
45.4\end{array}$ & $1.89 \%$ \\
\hline untested for $B R C A 1$ in family & 115 & 2 & $1.74 \%$ & 1 & $0.87 \%$ & 0 & 34.5 & $\begin{array}{l}31.5- \\
40.9\end{array}$ & $0.80 \%$ \\
\hline untested for $B R C A 2$ in family & 135 & 1 & $0.74 \%$ & 2 & $1.48 \%$ & 1 & 38.3 & $\begin{array}{l}31.7- \\
46.1\end{array}$ & $0.94 \%$ \\
\hline $\begin{array}{l}\text { negative for other actionable } \\
\text { gene }\end{array}$ & 13 & 0 & $0.00 \%$ & 2 & $15.38 \%$ & 0 & 36.2 & $\begin{array}{l}34.0- \\
42.3\end{array}$ & $0.09 \%$ \\
\hline untested for other gene & 10 & 0 & $0.00 \%$ & 0 & $0.00 \%$ & 0 & 35.1 & $\begin{array}{l}28.2- \\
42.3\end{array}$ & $0.07 \%$ \\
\hline \multicolumn{10}{|c|}{$\begin{array}{l}\text { No known high or moderate risk gene in family or individual including } \\
\text { untested }\end{array}$} \\
\hline high & 4939 & 217 & $4.39 \%$ & 171 & $3.46 \%$ & 69 & 39.7 & $\begin{array}{l}34.7- \\
47.0\end{array}$ & $34.53 \%$ \\
\hline moderate risk & 5234 & 181 & $3.46 \%$ & 37 & $0.71 \%$ & 73 & 40.3 & $\begin{array}{l}34.2- \\
46.5\end{array}$ & $36.59 \%$ \\
\hline Average/population risk & 2501 & 48 & $1.92 \%$ & 0 & $0.00 \%$ & 82 & 41.5 & $\begin{array}{l}33.9- \\
34.7\end{array}$ & $17.48 \%$ \\
\hline Total & 14311 & 649 & $4.51 \%$ & 455 & $3.18 \%$ & 269 & & & $100.00 \%$ \\
\hline
\end{tabular}

RRM-Risk reducing mastectomy; IQR-Interquartile range; BC-Breast cancer

Table 2: Incidence rates for breast cancer by $B R C A 1 / 2$ and risk group 


\begin{tabular}{|lllllll|}
\hline & number & follow up & BC & BC annual rate & prevalent & \% prevalent \\
\hline BRCA1* & 309 & 1738.39 & 30 & $1.73 \%$ & 2 & $0.65 \%$ \\
\hline BRCA2* & 312 & 1811.26 & 28 & $1.55 \%$ & 2 & $0.64 \%$ \\
\hline moderate in screening & 5293 & 28087.29 & 100 & $0.36 \%$ & 19 & $0.36 \%$ \\
\hline high risk in screening & 5129 & 30392.28 & 192 & $0.63 \%$ & 29 & $0.57 \%$ \\
\hline moderate off screening & & 22091.61 & 83 & $0.38 \%$ & $\mathrm{~N} / \mathrm{a}$ & \\
\hline High risk off screening & & 13298.49 & 81 & $0.61 \%$ & $\mathrm{~N} / \mathrm{a}$ & \\
\hline Average & 2509 & 23924.80 & 49 & $0.20 \%$ & 1 & $0.04 \%$ \\
\hline Negative for family BRCA2 & 218 & 1458.97 & 6 & $0.41 \%$ & 0 & \\
\hline Negative for family BRCA1 & 194 & 1379.21 & 4 & $0.29 \%$ & 0 & \\
\hline Untested for family BRCA1+ & 167 & 2390.28 & 7 & $0.29 \%$ & 3 & $1.80 \%$ \\
\hline Untested for family BRCA2+ & 180 & 2546.92 & 8 & $0.31 \%$ & 5 & $2.78 \%$ \\
\hline & 14311 & 129119.52 & 588 & & 61 & \\
\hline
\end{tabular}

* includes 31 tested on research basis who have not had clinical testing including 7 BRCA1/2 with breast cancer +includes women tested after censor and follow up in women who later tested positive or negative but these numbers not included in total women. BC-breast cancer

Table 3: Gene status in women with breast cancer with age at diagnosis and whether on or off programme 


\begin{tabular}{|c|c|c|c|c|c|c|c|c|c|c|c|c|c|}
\hline gene/risk & $\begin{array}{l}\text { Total } \\
\text { breast } \\
\text { cancer }\end{array}$ & $\begin{array}{l}\text { On } \\
\text { screening } \\
\text { program }\end{array}$ & $\begin{array}{l}\text { median } \\
\text { age }\end{array}$ & range & IQR & died & $\%$ died & $\begin{array}{l}\text { Off } \\
\text { screening } \\
\text { programme }\end{array}$ & $\begin{array}{l}\text { median } \\
\text { age }\end{array}$ & range & IQR & died & $\%$ died \\
\hline$B R C A 1$ & 77 & 60 & 43.2 & $\begin{array}{l}29.5- \\
61.3\end{array}$ & $\begin{array}{l}36.6- \\
48.7\end{array}$ & 8 & $13.79 \%$ & 17 & 42.5 & $\begin{array}{l}27.7- \\
66.4\end{array}$ & $\begin{array}{l}38.0- \\
53.5\end{array}$ & 3 & $17.65 \%$ \\
\hline$B R C A 2$ & 78 & 59 & 46.9 & $\begin{array}{l}28.7- \\
77.1\end{array}$ & $\begin{array}{l}39.3- \\
52.0\end{array}$ & 8 & $13.79 \%$ & 19 & 54.2 & $\begin{array}{l}40.4- \\
71.4\end{array}$ & $\begin{array}{l}48.7- \\
60.3\end{array}$ & 3 & $15.79 \%$ \\
\hline ATM & 9 & 8 & 47.4 & $\begin{array}{l}39.8- \\
53.36\end{array}$ & $\begin{array}{l}46.0- \\
52.5\end{array}$ & 1 & $16.67 \%$ & 1 & 41.6 & 41.0 & & 0 & $0.00 \%$ \\
\hline $\mathrm{CDH1}$ & 2 & 1 & 50.3 & & & 1 & $100.00 \%$ & 1 & 51.3 & & & 1 & $100.00 \%$ \\
\hline PTEN & 2 & 2 & 39.9 & $\begin{array}{l}38.4- \\
41.4\end{array}$ & & 0 & $0.00 \%$ & 0 & & & & 0 & \\
\hline PALB2 & 6 & 6 & 44.7 & $\begin{array}{l}41.6- \\
46.5\end{array}$ & $\begin{array}{l}44.5- \\
45.4\end{array}$ & 1 & $16.67 \%$ & 0 & & & & 0 & $0.00 \%$ \\
\hline CHEK2 & 7 & 4 & 43.4 & $\begin{array}{l}35.6- \\
46.1\end{array}$ & $\begin{array}{l}36.9- \\
44.1\end{array}$ & 0 & $0.00 \%$ & 3 & 64.4 & $\begin{array}{l}54.4- \\
74.5\end{array}$ & & 3 & $100.00 \%$ \\
\hline TP53 & 3 & 1 & 24.1 & 24.1 & & 0 & $0.00 \%$ & 2 & 32.4 & $\begin{array}{l}28.9- \\
35.9\end{array}$ & & 1 & $50.00 \%$ \\
\hline $\begin{array}{l}\text { negative for } \\
\text { family } \\
B R C A 1\end{array}$ & 5 & 3 & 54.3 & $\begin{array}{l}47.4- \\
56.9\end{array}$ & & 0 & $0.00 \%$ & 2 & 51.2 & & & 0 & $0.00 \%$ \\
\hline $\begin{array}{l}\text { negative for } \\
\text { family } \\
B R C A 2\end{array}$ & 10 & 4 & 54.1 & $\begin{array}{l}49.7- \\
59.3\end{array}$ & $\begin{array}{l}51.2- \\
57.3\end{array}$ & 1 & $25.00 \%$ & 6 & 52.2 & $\begin{array}{l}44.5- \\
53.1\end{array}$ & $\begin{array}{l}49.8- \\
52.6\end{array}$ & 0 & $0.00 \%$ \\
\hline $\begin{array}{l}\text { Untested } \\
B R C A 1\end{array}$ & 2 & & & & & & & 2 & 53.8 & $\begin{array}{l}41.5- \\
66.0\end{array}$ & & 1 & $50.00 \%$ \\
\hline $\begin{array}{l}\text { Untested } \\
B R C A 2\end{array}$ & 1 & & & & & & & 1 & 56.5 & & & 0 & $0.00 \%$ \\
\hline $\begin{array}{l}\text { Average risk } \\
\text { negative } \\
B R C A 1 / 2\end{array}$ & 22 & 3 & 55.0 & $\begin{array}{l}48.3- \\
64.9\end{array}$ & & 3 & $100.00 \%$ & 19 & 55.9 & $\begin{array}{l}31.4- \\
66.6\end{array}$ & $\begin{array}{l}51.6- \\
58.3\end{array}$ & 4 & $21.05 \%$ \\
\hline $\begin{array}{l}\text { Moderate } \\
\text { risk negative } \\
B R C A 1 / 2\end{array}$ & 121 & 78 & 47.9 & $\begin{array}{l}34.3- \\
65.5\end{array}$ & $\begin{array}{l}44.5- \\
52.1\end{array}$ & 14 & $17.50 \%$ & 43 & 56.2 & $\begin{array}{l}30.2- \\
78.1\end{array}$ & $\begin{array}{l}48.5- \\
65.4\end{array}$ & 5 & $11.63 \%$ \\
\hline $\begin{array}{l}\text { High risk } \\
\text { negative } \\
B R C A 1 / 2\end{array}$ & 176 & 131 & 49.7 & $\begin{array}{l}29.6- \\
66.6\end{array}$ & $\begin{array}{l}44.9- \\
54.8\end{array}$ & 14 & $10.53 \%$ & 45 & 54.7 & $\begin{array}{l}32.1- \\
79.2\end{array}$ & $\begin{array}{l}50.1- \\
67.3\end{array}$ & 9 & $20.00 \%$ \\
\hline $\begin{array}{l}\text { Average risk } \\
\text { no testing }\end{array}$ & 26 & 0 & & & & 0 & & 26 & 55.7 & $\begin{array}{l}41.3- \\
86.6\end{array}$ & $\begin{array}{l}51.8- \\
63.0\end{array}$ & 11 & $42.31 \%$ \\
\hline $\begin{array}{l}\text { Moderate } \\
\text { risk no } \\
\text { testing }\end{array}$ & 61 & 17 & 48.4 & $\begin{array}{l}34.4- \\
64.0\end{array}$ & $\begin{array}{l}46.4- \\
53.4\end{array}$ & 1 & $5.88 \%$ & 44 & 55.3 & $\begin{array}{l}27.6- \\
71.1\end{array}$ & $\begin{array}{l}51.1- \\
62.6\end{array}$ & 10 & $22.73 \%$ \\
\hline $\begin{array}{l}\text { High risk no } \\
\text { testing }\end{array}$ & 41 & 17 & 45.9 & $\begin{array}{l}33.0- \\
63.0\end{array}$ & $\begin{array}{l}44.8- \\
54.8\end{array}$ & 2 & $11.11 \%$ & 24 & 56.7 & $\begin{array}{l}35.5- \\
71.1\end{array}$ & $\begin{array}{l}47.7- \\
64.6\end{array}$ & 2 & $8.33 \%$ \\
\hline Total & 649 & 394 & & & & 54 & $13.81 \%$ & 255 & & & & 53 & $20.78 \%$ \\
\hline
\end{tabular}

IQR-Interquartile range; BC-Breast cancer

Table 4: Pathology details by genetic testing and risk group of breast cancers identified on the screening programme 


\begin{tabular}{|c|c|c|c|c|c|c|c|c|c|c|c|c|}
\hline gene/risk & $B R C A 1$ & BRCA2 & ATM & $\mathrm{CDH1}$ & PTEN & PALB2 & CHEK2 & TP53 & $\begin{array}{l}\text { Negative } \\
\text { for } \\
\text { family } \\
\text { BRCA } \\
\text { mutation }\end{array}$ & $\begin{array}{l}\text { Average } \\
\text { risk }\end{array}$ & $\begin{array}{l}\text { Moderate } \\
\text { risk } \\
\text { negative } \\
B R C A 1 / 2\end{array}$ & $\begin{array}{l}\text { High risk } \\
\text { negative } \\
B R C A 1 / 2\end{array}$ \\
\hline $\begin{array}{l}\text { On breast } \\
\text { screening } \\
\text { programme }\end{array}$ & 60 & 59 & 8 & 1 & 2 & 6 & 4 & 1 & 7 & 3 & 78 & 131 \\
\hline \multicolumn{13}{|c|}{ Timing of cancer diagnosis } \\
\hline Prevalent & 5 & 7 & 0 & 0 & 0 & 0 & 1 & 0 & 1 & 1 & 17 & 9 \\
\hline Incident & 37 & 42 & 8 & 1 & 2 & 4 & 2 & 1 & 6 & 0 & 43 & 87 \\
\hline $\begin{array}{l}\text { Interval } \\
\% \text { interval }\end{array}$ & $\begin{array}{l}18 \\
(30.0 \%)\end{array}$ & $\begin{array}{l}10 \\
(16.9 \%)\end{array}$ & $\begin{array}{l}0 \\
0.0 \%\end{array}$ & $\begin{array}{l}0 \\
0.0 \%\end{array}$ & $\begin{array}{l}0 \\
0.0 \%\end{array}$ & $\begin{array}{l}2 \\
33.3 \%\end{array}$ & $\begin{array}{l}1 \\
25.0 \%\end{array}$ & $\begin{array}{l}0 \\
0.0 \%\end{array}$ & $0 \quad 0.0 \%$ & $\begin{array}{l}2 \\
66.7 \%\end{array}$ & $1823.1 \%$ & $\begin{array}{l}35 \\
26.7 \%\end{array}$ \\
\hline $\begin{array}{l}\text { Interval at } \\
\text { BRRM }\end{array}$ & 2 & 2 & & 1 & & & 1 & & & & & 1 \\
\hline \multicolumn{13}{|l|}{ Type of cancer } \\
\hline IDC Grade 1 & 0 & 3 & 0 & 0 & 0 & & 1 & 0 & 0 & 1 & 10 & 26 \\
\hline P value Grade 1 & $<0.0001$ & 0.004 & & & & & & & & & 0.18 & Reference \\
\hline IDC Grade 2 & 7 & 18 & 2 & 0 & 1 & 2 & 1 & 0 & 2 & 0 & 25 & 35 \\
\hline IDC Grade 3 & 48 & 21 & 1 & 0 & 0 & 4 & 1 & 1 & 3 & 0 & 25 & 32 \\
\hline$\%$ Grade 3 & $80.0 \%$ & $35.6 \%$ & $12.5 \%$ & $0.0 \%$ & $0.0 \%$ & $66.7 \%$ & $25.0 \%$ & $100.0 \%$ & $42.9 \%$ & $0.0 \%$ & $32.1 \%$ & $24.4 \%$ \\
\hline $\begin{array}{l}\text { Grade } 3 \text { vs high } \\
\text { risk no PV* }\end{array}$ & $<0.0001$ & 0.24 & & & & & & & & & 0.73 & Reference \\
\hline ILC & 0 & 3 & 1 & 1 & 0 & 0 & 0 & 0 & 0 & 2 & 5 & 17 \\
\hline$P$ value* & $<0.0001$ & 0.1 & & & & & & & & & 0.16 & Reference \\
\hline CIS & 5 & 14 & 4 & 0 & 1 & 0 & 1 & 0 & 2 & 0 & 13 & 21 \\
\hline$\% \mathrm{CIS}$ & $8.3 \%$ & $23,7 \%$ & $50.0 \%$ & $0.0 \%$ & $50.0 \%$ & $0.0 \%$ & $25.0 \%$ & $0.0 \%$ & $28.6 \%$ & $0.0 \%$ & $16.7 \%$ & $16.0 \%$ \\
\hline$P$ value* & 0.18 & 0.08 & & & & & & & & & 1.0 & Reference \\
\hline \multicolumn{13}{|c|}{ Cancer characteristics } \\
\hline LN negative in & 40 & 34 & 4 & 1 & 1 & 4 & 3 & 1 & 3 & 1 & 46 & 80 \\
\hline$\% \mathrm{LN}^{0}$ & $72.7 \%$ & $75.6 \%$ & $100.0 \%$ & $100.0 \%$ & $100.0 \%$ & $66.7 \%$ & $100.0 \%$ & $100.0 \%$ & $60.0 \%$ & $33.3 \%$ & $70.8 \%$ & $72.7 \%$ \\
\hline Stage 1 & 35 & 30 & $250.0 \%$ & 0 & 0 & 2 & 3 & 1 & 3 & 1 & 36 & 69 \\
\hline$\%$ of invasive & $63.6 \%$ & $66.7 \%$ & & $0.0 \%$ & $0.0 \%$ & $33.3 \%$ & $100.0 \%$ & $100.0 \%$ & $60.0 \%$ & $33.3 \%$ & $55.4 \%$ & $62.7 \%$ \\
\hline Invasive $\leq 20 \mathrm{~mm}$ & 39 & 36 & 1 & 0 & 0 & 2 & 3 & 1 & 4 & 1 & 48 & 82 \\
\hline$\%$ & $73.6 \%$ & $83.7 \%$ & $33.3 \%$ & $0.0 \%$ & $0.0 \%$ & $33.3 \%$ & $100.0 \%$ & $100.0 \%$ & $80.0 \%$ & $33.3 \%$ & $73.8 \%$ & $74.5 \%$ \\
\hline \multirow[t]{2}{*}{ ER- } & 42 & 14 & 0 & 0 & 0 & 1 & 0 & 0 & 0 & 1 & 22 & 16 \\
\hline & $<0.0001$ & 0.05 & & & & & & & & & 0.004 & Reference \\
\hline HER2+ & 0 & 2 & 0 & 0 & 0 & & 0 & 0 & 0 & 0 & 7 & 5 \\
\hline
\end{tabular}

\section{Figures}




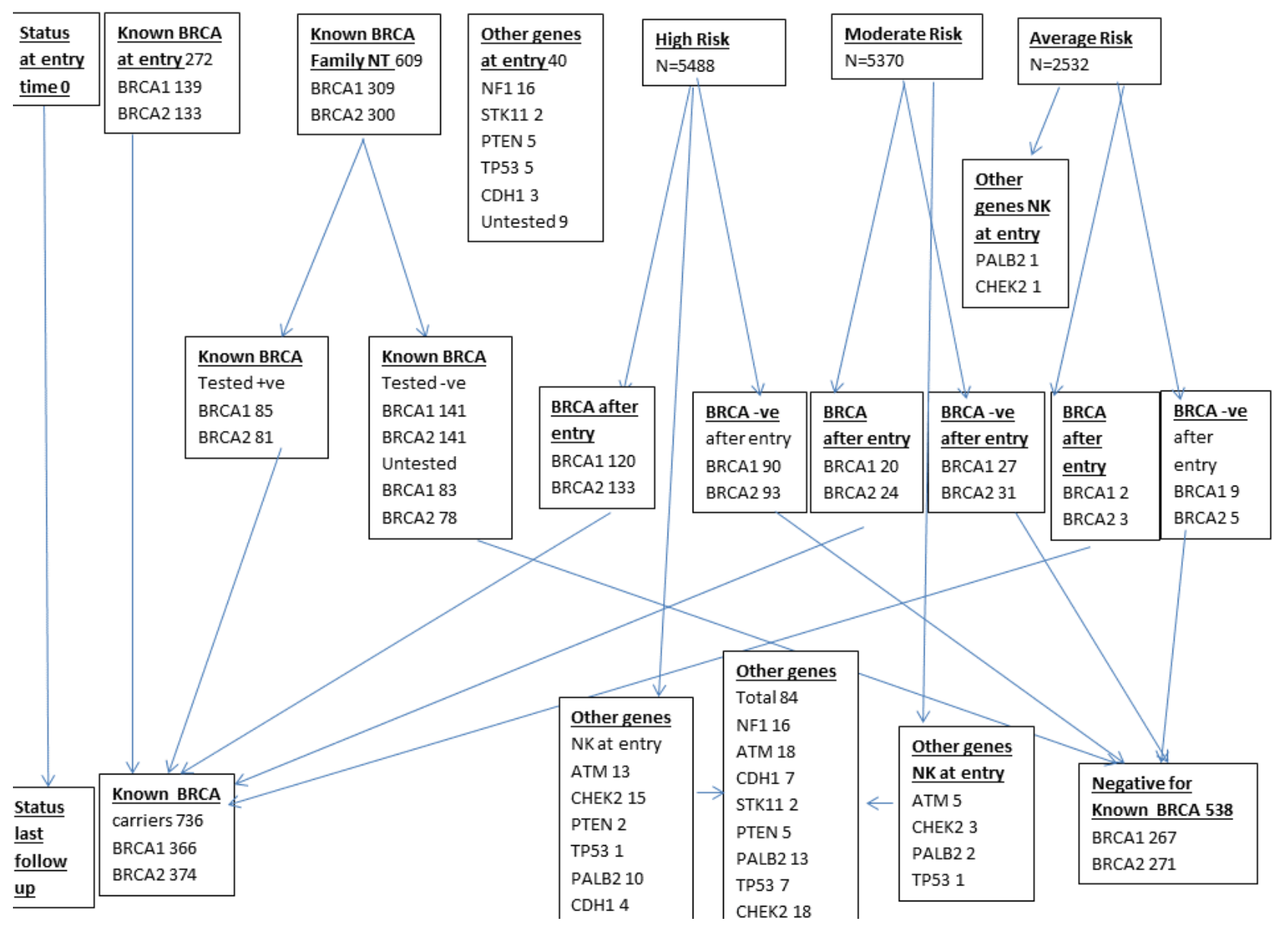

Figure 1

Flow diagram of Gene status and risk at entry and later Foot notes: NT-not tested; NK-not known; BRCA -ve negative for known BRCA PV in family; BRCA +ve positive for known BRCA PV in family

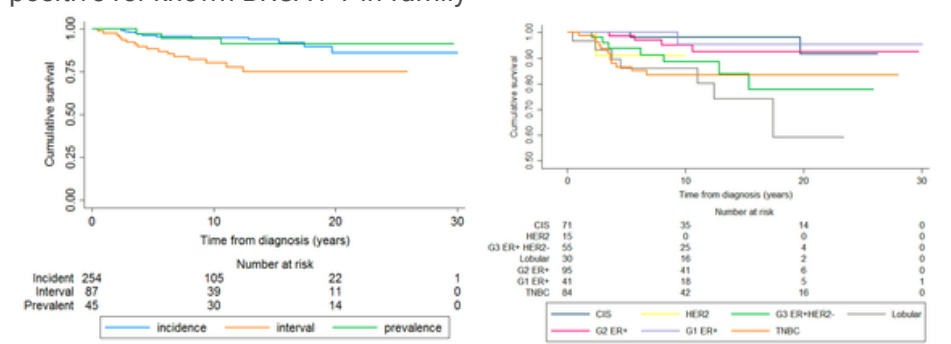

A

B

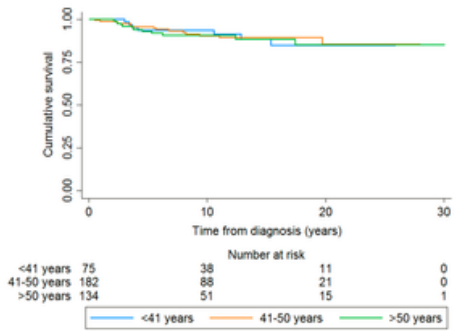

C

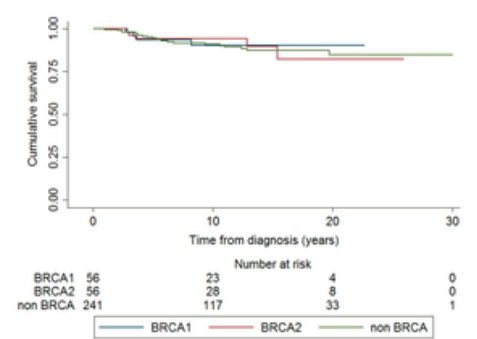

D

Figure 2

a: Survival by presentation (interval, incident, prevalent) - breast cancer deaths Incidence vs interval $(p<0.001)$, prevalence vs incidence ( $p=0.052)$ b: Survival by pathology type - breast cancer deaths TNBC vs G1 ER+ ( $p=0.04), G 2$ ER+ (, $p=0.03), C I S(p=0.01) ; G 1 E R+$ vs lobular ( $p=0.015)$; G2 ER+ vs lobular $(p=0.006)$; lobular vs CIS ( $p<0.001)$; G3 ER+ HER2- vs CIS ( $p=0.019)$ TNBC - triple negative breast cancer, CIS - carcinoma in situ, G - grade, ER - estrogen receptor, HER2 - human epidermal growth factor receptor $2 \mathrm{c}$ : Survival by age group - breast cancer deaths d: Kaplan Meier breast cancer specific survival curves comparing BRCA1, BRCA2, and non-BRCA affected women

\section{Supplementary Files}

This is a list of supplementary files associated with this preprint. Click to download.

- SupplementaryTable1.docx 